\title{
Labor Harassment in the Brazilian Legal System
}

\author{
Rocco Antonio Rangel Rosso Nelson ${ }^{*}$, Walkyria de Oliveira Rocha Teixeira ${ }^{1}$, \\ Rafael Laffitte Fernandes', Fabrício Germano Alves ${ }^{2}$, Thiago de Bessa da Silva1, \\ Thiago Murilo Nobrega Galvão ${ }^{3}$, Matheus Gomes Amorim ${ }^{1}$
}

\author{
${ }^{1}$ Federal Institute of Rio Grande do Norte, Natal, Brazil \\ ${ }^{2}$ Federal University of Rio Grande do Norte, Natal, Brazil \\ ${ }^{3}$ University Center of Rio Grande do Norte, Natal, Brazil \\ Email: *rocconelson@hotmail.com, walkyria.teix eira@ifrn.edu.br, Rafael.laffitte@ifrn.edu.br, fabriciodireito@gmail.com, \\ thiago.bessa@ifrn.edu.br, thiagonobrega@icloud.com, matheusgomesrn@gmail.com
}

How to cite this paper: Nelson, R. A. R. R., de Oliveira Rocha Teixeira, W., Fernandes, R. L., Alves, F. G., de Bessa da Silva, T., Galvão, T. M. N., \& Amorim, M. G. (2019). Labor Harassment in the Brazilian Legal System. Beijing Law Review, 10, 487-504. https://doi.org/10.4236/blr.2019.103030

Received: April 15, 2019

Accepted: June 2, 2019

Published: June 5, 2019

Copyright $\odot 2019$ by author(s) and Scientific Research Publishing Inc. This work is licensed under the Creative Commons Attribution International License (CC BY 4.0).

http://creativecommons.org/licenses/by/4.0/

\begin{abstract}
Work is an umbilically linked activity with all spheres of a person's life, since a significant part of the human being's working life is reflected in the personal, family, and social dimensions of the worker. In such a way, a healthy working environment is crucial for the good development of the person, in all said dimensions. It is for no other reason that social rights are erected to human rights status. The objective of this essay is precisely to verify the normative juridical contours that allow the subsumption of conduct as a form of moral harassment, and in these terms, the legal consequence of said practice. The on-screen research, using a methodology of qualitative analysis, using the hypothetical-deductive approaches of a descriptive and analytical character, adopting a bibliographic research technique, has its background on a dogmatic analysis of the construction Normative of the conduct of moral harassment in the bulge of the Brazilian juridical system having by axiological vector, always, the search of the effectiveness of the fundamental rights carved in the Federal Constitution of 1988.
\end{abstract}

\section{Keywords}

Harassment, Features, Legal Forecast, Positioning of Court

\section{Introduction}

Bullying has several denominations in comparative law: "acoso moral" in Spain; "Mobbing" in Italy, Germany; "Ijime" in Japan; "Bullying" in England; "harassmente" in the United States; "harcèlement moral" in France. The terminology of psychoterrorism is also common. 
The so-called labor harassment is actually the result of the appropriation of the terminology "mobbing" used in science that studies animal behavior (ethology) which is related to the collective practice of animals practice hostile behavior with the aim of banishing one of its members from the conviviality of the pack.

Mobbing in the workplace was only used in the 1980s by labor psychologist Heinz Leymann. This terminology and the subject, in itself, gained prominence and importance in its study since 1998 with the work of the French psychoanalyst Marie-France Hirigoyen (Harcèlement moral: démêler le vrai du faux). (Cf. CASTRO, 2014: pp. 20-21)

(Leymann, 1990) was the first to define the working mobbing, presenting the theme as follows:

Psychical terror or mobbing in working life means hostile and unethical communication which is directed in a systematic way by one or a number of persons mainly toward one individual. There are also cases where such mobbing is mutual until one of the participants becomes the underdog. These actions take place often (almost every day) and over a long period (at least for six months) and, because of this frequency and duration, result in considerable psychic, psychosomatic and social misery. This definition eliminates temporary conflicts and focuses on the transition zone where the psychosocial situation starts to result in psychiatric and/or psychosomatic pathological states. (p. 120)

In his bestseller, (Hirigoyen, 2002) presents the following definition on the subject:

Por assédio em um local de trabalho temos que entender total e qualquer conduta abusiva, manifestando-se sobretudo por comportamentos, palavras, atos, gestos, escritos que possam trazer dano à personalidade, à dignidade ou à integridade física ou psíquica de uma pessoa, por em perigo seu emprego ou degradar o ambiente de trabalho. (p. 65) ${ }^{1}$

The definition of (Castro, 2014), seeks to present all the characteristics of bullying:

Violência moral intensa praticada por um agente (ou mais), em regra, o empregador ou superior hierárquico (assédio moral “vertical descendente”), porém, pode ser efetuado por subordinado (assédio moral “ascendente”), por colega de trabalho (assédio moral “horizontal”) ou por terceiro não vinculado à hierarquia empresarial. Os atos ofensivos devem ser dolosos ou simplesmente ter por efeito provocar um dano, não desejado, à dignidade ou integridade moral de uma ou de muitas vítimas no trabalho e ocorrem através de uma série de ações-em que cada uma das quais aparece isoladamente como lícita ou ilícita, embora na realidade seja simples fração da atuação total-unidas entre si pela sistematização das circunstancias que se repetem durante um período (normalmente de duração longa, lenta e gradual), que, no conjunto, constituem, por ficção, fato un${ }^{1}$ Free translation: "Through harassment in a workplace we have to understand total and any abusive conduct, manifesting above all by behaviors, words, acts, gestures, writings that can harm the personality, dignity or physical or mental integrity of a person, for jeopardizing their employment or degrading the work environment". 
itário e unidade jurídica, para todos os efeitos de Direitoº. (p. 143)

In a true and authentic interpretation, the State Law of Rio de Janeiro no. 3.921 of 2002, presents the following definition of moral harassment, in its art. $2^{\circ}$ :

Art. $2^{\circ}$-The employee, employee or employee's exposure to humiliating or embarrassing situations, or any action, or word of gesture, that is practiced in a repetitive and prolonged manner, is considered harassment at work, for the purposes of this Law, during the working day of the organ or entity, and, by agent, delegate, supervisor or hierarchical supervisor or any representative who, in the exercise of his or her functions, abusing the authority conferred upon him, has the purpose or effect of achieving the self-esteem and self-determination of the subordinate, with damages to the work environment, to the services rendered to the public and to the own user, as well as, to hinder the evolution of the career or the functional stability of the constrained server. ${ }^{3}$

It is important to emphasize that as lege ferenda there is Bill no. 4.593/09 of the former federal deputy Nelson Goetten, which deals specifically with moral harassment in labor relations, which thus presents the concept of moral harassment:

Art. $1^{\circ}$. (...).

$\$ 1^{\circ}$ It is understood by harassment the repeated and abusive subjection of the employee to humiliating or degrading working conditions, implying a violation of their human dignity by the employer or his employees or a group of employees, as well as omission in the prevention and punishment for the occurrence of bullying. ${ }^{4}$

\section{Classifications as to Moral Harassment}

\subsection{From the Classification as to the Hierarchical Degree}

This classification is the most used and has by vertex the hierarchical degree of the stalking agent, being classified in descending vertical moral harassment; ascending vertical moral harassment; horizontal harassment; and mixed harassment.

In downright vertical bullying the stalker is the figure of the employer or person of superior hierarchical level with power of warrant in relation to the victimized worker. An asymmetrical relationship of power between the parties is evident.

This figure is also known as "bossing" (Cf, Castro, 2014: p. 54) and is the most common one to happen and to last, given the legal subordination of the labor

${ }^{2}$ Free translation: "Intense moral violence practiced by an agent (or more), as a rule, the employer or hierarchical superior ('downward vertical' bullying), however, can be effected by subordinate ('upward' bullying), by co-worker (harassment moral 'horizontal') or third party not linked to the business hierarchy. Offensive acts must be malicious or simply have the effect of causing undesirable damage to the dignity or moral integrity of one or many victims at work and occur through a series of actions-each of which appears separately as lawful or illicit, although in reality it is a simple fraction of the total performance- united together by the systematization of the circumstances that are repeated during a period (usually of long, slow and gradual duration), which together constitute, by fiction, unitary fact and legal unit, for all purposes of law".

${ }^{3}$ Free translation.

${ }^{4}$ Free translation. 
contract and the economic dependence of the victim. ${ }^{5}$

(Soares \& Duarte, 2014: p. 32) Alleged bullying is difficult to practice on the part of the subordinates in relation to the hierarchical superior (example of motivation-the boss is very young and manages subordinates many older, lack of experience and security, superior coming from another company). ${ }^{6}$ Generally, in this case, give the association for more than a subordinate to pursue and denigrate the figure of superior practicing insubordination, sarcasm, etc.

Horizontal harassment occurs when the mobilizing practice is perpetrated by people of the same hierarchical level, lacking hierarchical superiority, usually triggered by interpersonal conflicts or rivalries of a professional nature. In such cases, the omission or lack of interest of the company to suppress such practices is common.

Finally, there is still mixed harassment or "combined mobbing" which consists of combining vertical and horizontal harassment to denigrate the victimized worker.

It is said that in this practice the harassment begins by the higher authority and comes to contaminate the co-workers, authorizing, implicitly that they carry out the said practice in relation to the harassed worker. The reverse is also true. The bullying practice gives itself in the horizontal level, coming to configure the vertical harassment by omission of the hierarchical superiors.

\subsection{The Classification as to the Degree of Damage}

In this classification the victim has an excessive focus, this being the reason for the criticism, since the fault is not of the harassed individual.

In first-degree harassment are passive behaviors to be absorbed by the worker and even dissociate himself from persecution in a way that does not entail exclusion from the work environment.

In the case of second-degree harassment, the worker can not get rid of the mobizers' behavior, since there is an affectation about his health, and there are difficulties in returning to the work environment (Cf, Castro, 2014: p. 60).

Finally, third-degree harassment of the harassed person is completely impossible to return to the environment and work, besides the difficulty of rehabilitation of the worker himself in the face of developed physical and psychiatric 5“DANO MORAL. IMITAÇÕES E APELIDOS PEJORATIVOS. ATENTADO À DIGNIDADE. INDENIZAÇAO DEVIDA. Confirmando a prova dos autos, a adoção pela reclamada, de forma injuriosa de gestão, valendo-se de reiterada prática de constrangimento moral imposto por superiora hierárquica (mobbing vertical descendente, ou simplesmente bossing), é de se reformar decisão que indeferiu à obreira indenização por dano moral decorrente da degradação do ambiente laboral, com manifesto atentado à dignidade das trabalhadoras e da reclamante em particular. Não se pode considerar "normal" que chefes imediatos humilhem seus subordinados, tanto mais quando passadas as ofensas em público. Os epítetos pejorativos dirigidos pela gerente à reclamante, como macaco, dentuça, atrapalhada, burra e cabeça de tomate, entre outros, além da imitação de um símio relacionando-o à empregada, têm notória feição vexatória, preconceituosa e discriminatória, de que resulta o dever de indenizar. Recurso da autora a que se dá provimento, no particular". (TRT da $2^{\circ}$ Região, Recurso Ordinário $\mathrm{n}^{\circ}$ 691200803702002 SP 00691-2008-037-02-00-2. Desembargador Relator Ricardo Artur Costa e Trigueiros. Julgado em 32 de março de 2009, publicado no DEJT em 17 de abril de 2009).

6“(...). Os motivos para a ocorrência das agressões podem ser, por exemplo, se o chefe é uma pessoa nova, vinda de fora, com métodos diferentes dos tradicionalmente utilizados na empresa, os quais não são aprovados pelo grupo. Pode ocorrer ainda em razão de uma promoção de um colega, sem que o restante do pessoal tenha sido consultado. A violência de subordinados contra superiores pode dar-se ainda quando um colega é promovido a um cargo de chefia cujas funções os subordinados supõem que o promovido não possui méritos para desempenhar". 
illnesses.

\subsection{From the Classification as the Motivation}

The latter classification focuses on the motivation behind harassment, dividing itself into emotional mobbing and strategic mobbing (Cf, Castro, 2014: p. 61).

The emotional "mobbing" the harassing behaviors are in the face of interpersonal relations where it develops feelings of envy, competition, antipathy, discrimination in face of race, color, gender, etc.

The strategic mobbing refers to the planning and execution of schemes designed to lead the unwanted worker to resign, which would reduce the amount of labor with the termination of the employment contract (Martins, 2015: p. 30). ${ }^{7}$

Exempli gratia of the practice of strategic mobbing has been in the banking system, in the not too distant past, where several banks with a view to reducing staffing began to pressure employees to join the voluntary resignation scheme, or overburden them with overwork and constant pressure to achieve goals unattainable with the purpose of which they resigned.

\section{Sources of the Right as to Moral Harassment}

Prefacially, it is essential to point out the absence of a heteronomous source, that is, of specific labor legislation on moral harassment, which, as already explained, is a normative construction deriving from doctrine and jurisprudence.

There is, as a lege ferenda, in the Chamber of Deputies, Bill No. 4593/09, which deals with moral harassment in labor relations, and an earlier project, Bill No. 2369/03, which modifies provisions of the Consolidation of Labor Laws-CLT, to provide for the prohibition of the practice of bullying in labor relations.

There are two scattered federal laws that, in their normative synthesis, forbid loans to companies convicted of bullying.

Law No. 11.514 of 2007, which establishes guidelines for the preparation and execution of the 2008 Budget Law and provides other provisions in its art. 96, $\$ 1$, IV the prohibition of the granting or renewal of loans or financings by official agencies institutions convicted of moral harassment.

Art. 96. (...)

$\S 1^{\circ}$ The granting or renewal of any loans or financing by the official development finance agencies is prohibited:

(...)

IV-institutions whose leaders are convicted of moral or sexual harassment, racism, child labor or slave labor. ${ }^{8}$

Law No. 11.948 of 2009 prohibits, in the same sense, granting or renewing any loans or financing by the National Development Bank to companies convicted of moral harassment.

Art. $4^{\circ}$ The granting or renewal of any loans or financing by the BNDES to

““(...). Ocorre quando o empregador quer que um empregado peça demissão para não arcar com o custo da despedida. É uma forma de livrar-se do empregado com o menor custo financeiro. Muitas vezes, o empregado é colocado na 'geladeira', de forma que peça demissão".

${ }^{8}$ Free translation. 
companies of the private initiative whose directors are condemned for moral or sexual harassment, racism, child labor, slave labor or crime against the environment is prohibited. ${ }^{9}$

In Regulatory Standard no. 17, which deals with ergonomics, in Annex II, which deals with the telemarketing/telemarketing work, there is a prohibition on the practice of bullying:

5.13. It is prohibited to use methods that cause moral harassment, fear or embarrassment, such as:

a) an abusive stimulus to competition between workers or groups/work teams;

b) demand that workers use, on a permanent or temporary basis, props, accessories, costumes and costumes for the purpose of punishment, promotion and propaganda;

c) public exposure of operators' performance appraisals. ${ }^{10}$

Obviously, the possibility of an autonomous source arising from agreements and collective bargaining agreements with clauses with the aim of curbing the practice of bullying is not heard.

Apart from this context of the private sector, the existence of a specific rule to detail the form of moral harassment, or even, simply, prohibiting its practice, is found in state and municipal legislations that organize the proper regime of their respective servers or specific laws that prohibit the practice within the Public Administration.

The first State to be concerned about the issue of bullying was that of Rio de Janeiro and created Law No. 3.921 of 2002 to discipline the subject. In the municipal sphere, the Municipality of Iracemápolis, in the State of São Paulo, was the first to create a municipal law on the matter (Law No. 1.163/00). ${ }^{11}$

There is no legal provision for bullying in federal legislation for Public Administration as there is state and municipal laws.

Under the provisions of Law No. 8.112/90, which establishes the legal regime for civil servants of the Federal Government, municipalities and federal public foundations, the conduct of moral harassment could be subsumed in theory in the disciplinary infractions regarding the duty to maintain conduct compatible with administrative morality or urban treatment, both provided for in art. 116 of

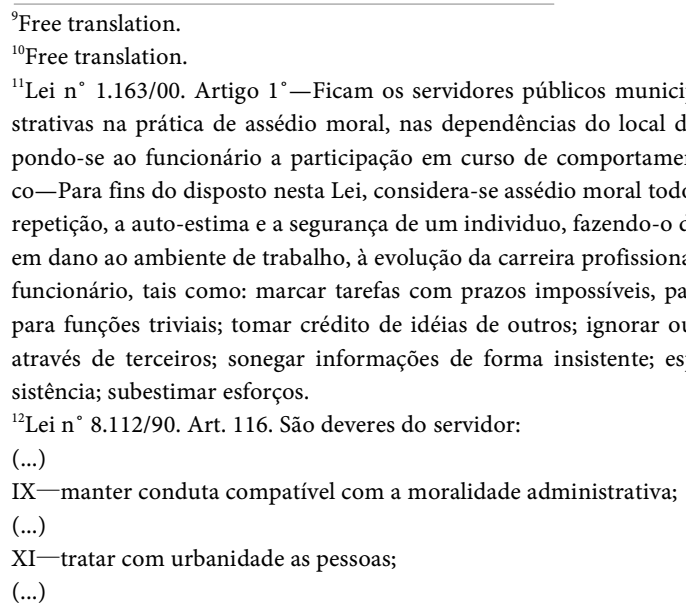


Law 8.112/90. ${ }^{12}$

It should also be pointed out that depending on the specific case, moral harassment can be a hypothesis of administrative impropriety (article 11 of Law 8.429/92), which had already been recognized by the Superior Court of Justice (STJ):

ADMINISTRATIVO. AÇÃO CIVIL PÚBLICA. IMPROBIDADE ADMINISTRATIVA. ASSÉDIO MORAL. VIOLAÇÃO DOS PRINCÍPIOS DA ADMINISTRAÇÃO PÚBLICA. ART. 11 DA LEI8.429/1992. ENQUADRAMENTO. CONDUTA QUE EXTRAPOLA MERA IRREGULARIDADE. ELEMENTO SUBJETIVO. DOLO GENÉRICO.

1) O ilícito previsto no art. 11 da Lei $8.249 / 1992$ dispensa a prova de dano, segundo a jurisprudência do STJ.

2) Não se enquadra como ofensa aos princípios da administração pública (art. 11 da LIA) a mera irregularidade, não revestida do elemento subjetivo convincente (dolo genérico).

3) O assédio moral, mais do que provocações no local de trabalho-sarcasmo, crítica, zombaria e trote -, é campanha de terror psicológico pela rejeição.

4) A prática de assédio moral enquadra-se na conduta prevista no art. 11, caput, da Lei de Improbidade Administrativa, em razão do evidente abuso de poder, desvio de finalidade e malferimento à impessoalidade, ao agir deliberadamente em prejuízo de alguém.

5) A Lei 8.429/1992 objetiva coibir, punir e/ou afastar da atividade pública os agentes que demonstrem caráter incompatível com a natureza da atividade desenvolvida.

6) Esse tipo de ato, para configurar-se como ato de improbidade exige a demonstração do elemento subjetivo, a título de dolo lato sensu ou genérico, presente na hipótese.

7) Recurso especial provido. (Our Griffins). ${ }^{13}$

\section{The Structuring Elements of the Moral Harassment}

In Law No. 4.593/09, it sets forth hypotheses (non-exhaustive role) of conduct that would subsume the figure of bullying:

Art. $2^{\circ}$. (...).

1) - the exposure of the employee to the embarrassing situation, practiced in a

${ }^{13}$ STJ, Segunda turma, REsp n ${ }^{\circ}$ 1286466/RS, Rel. Min. Eliana Calmon, julgado em 03/09/2013, DJe 18/09/2013. Free translation: "ADMINISTRATIVE. PUBLIC CIVIL ACTION. ADMINISTRATIVE DISHONESTY. MORAL HARASSMENT. VIOLATION OF THE PRINCIPLES OF PUBLIC ADMINISTRATION. ART. 11 OF LAW 8,429/1992. FRAMEWORK. EXTRAPOLA CONDUCT MERE IRREGULARITY. SUBJECTIVE ELEMENT. GENERIC DOLO. 1) The offense established in art. 11 of Law 8.249/1992 exempts evidence of damage, according to the jurisprudence of the STJ. 2) It is not an offense to the principles of public administration (Article 11 of the LIA) to be mere irregularity, not covered by the convincing subjective element (generic malice). 3) Bullying, rather than provocation in the workplace-sarcasm, criticism, mockery and trot-is a campaign of psychological terror by rejection. 4) The practice of moral harassment is in accordance with the conduct set forth in art. 11, caput, of the Law of Administrative Improbity, due to the evident abuse of power, misuse of purpose and malfeasance to impersonality, by acting deliberately to the detriment of someone. 5) Law 8.429/1992 aims to restrain, punish and/or exclude from public activity agents that demonstrate a character incompatible with the nature of the activity developed. 6) This type of act, to be configured as an act of improbability requires the demonstration of the subjective element, as dolo lato sensu or generic, present in the hypothesis. 7) Special appeal provided". 
repetitive or prolonged way;

2)-psychological torture, contempt and the forfeiture of information that is necessary for the good performance of the employee's functions or useful for the performance of work;

3) - the employee's exposure, to the detriment of his or her personal and professional development, to repeated and unfounded criticism that affects his physical and mental health, his honor and dignity, and his family;

4) - the appropriation of the credit of the employee's work, with disrespect to the respective authorship;

5) - the determination of foreign assignments or activities that are incompatible with the employment contract or under unconditional terms and conditions;

6)-the obsolescence, by any means, of the evolution of the employee in the respective career;

7)-the occurrence of the hypotheses provided for in items 'a', 'b', 'd', 'e' and ' $\mathrm{g}$ ', of art. 483 of the Consolidation of Labor Laws, approved by Decree-Law No. 5,452, dated May $1,1943 .{ }^{14}$

The aforementioned bill proposes only moral harassment. So the key question is asked: what elements would constitute the phenomenon of bullying?

\subsection{From the Work Context}

In order to be able to refer to workplace harassment, firstly, it is required that such abusive conduct should happen in relation to the work environment (dependencies of the workplace) or according to work.

Although there is no need to strictly confine oneself to the physical space of work, the causal link with the social reality of work is fundamental, under penalty of being limited to the circumscription of the business establishment, stratospheric way going beyond the labor context.

\subsection{From Repeated and Systemic Practice}

Bullying is defined by a set of behaviors (several acts), repeated over a certain period of time, which ultimately damages the worker's personality rights. ${ }^{15}$

An isolated act can conform to a moral aggression with repercussion in the civil, criminal and labor sphere. However, it does not constitute harassment in

\footnotetext{
${ }^{14}$ Free translation.

${ }^{15}$ INDENIZAÇÃO POR ASSÉDIO MORAL. NÃO CARACTERIZAÇÃO DOS FATOS. Assédio significa submeter sem trégua a pequenos ataques repetidos. Trata-se, portanto, de ato que só adquire significado pela insistência visando atingir a autoestima da pessoa. O termo moral, por sua vez, quer dizer o que é ou não aceitável na sociedade, havendo valoração de acordo com o contexto social. Diante da inexistência de legislação específica sobre assédio moral no âmbito da relação de emprego, e a partir do seu conceito, exsurgem como elementos caracterizadores do instituto: a) identificação dos sujeitos; b) conduta, comportamento e atos atentatórios aos direitos da personalidade; c) reiteração e sistematização; e d) consciência do agente. Na situação em apreço, ao analisar o conjunto probatório percebo que o autor não logrou demonstrar satisfatoriamente os fatos que teriam gerado o assédio. Nessa seara, despicienda a persecução processual no sentido de se conjuminar os fatos narrados com os traços característicos do assédio moral, à míngua de elementos aptos a comprová-los. MULTA DO ART. 477 DA CLT. NÃO INCIDÊNCIA. A homologação rescisória operada em data posterior aos prazos previstos no parágrafo $6^{\circ}$ do art. 477 da CLT não atrai a multa preconizada no parágrafo $8^{\circ}$ do mesmo artigo se o reclamado procedeu, tempestivamente, ao depósito do valor correspondente às verbas resilitórias em conta bancária do obreiro. Recurso do reclamante parcialmente conhecido e parcialmente provido. Recurso da reclamada conhecido e não provido. (Grifos nossos) (TRT da $10^{\circ}$ região, $3^{\circ}$ turma, RO 1149201110110007, relatora Desembargadora Márcia Mazoni Cúrcio Ribeiro, julgado em 21/11/2012, DEJT de 30/11/2012).
} 
the employment relationship.

The time lag in which this sum of acts would constitute bullying is mathematically quantified by some doctrinators, with fractions of time being ventilated for 6 months to 1 year.

It is not believed that obeying a fixed time frame is the best way to impute the subsumption of the labor fact as bullying. In reality it would be better to assess case by case and from the ventilated evidence determine whether to face a real labor moral harassment or actions of isolated moral aggression.

Another way of thinking would be to expose the protection of the worker's dignity in various situations.

In this sense is the best labor jurisprudence that has glimpsed the bullying in the very short time span of the notice.

\subsection{Damaging Outcome}

The controversy under which the harmful damaging result from the practice of moral harassment relates to the necessity or not to clinically assess the physical and psychological health dimension of the harassed worker (Martins, 2015: p. 21). ${ }^{16}$

We map together with part of the doctrine that recognizes the necessity of the injury (damage) as essential for the configuration of moral harassment, not being necessary, however, the presence of damage to the health of the worker.

The conduct of mobbing can harm a plexus of fundamental rights of the worker, such as honor, freedom of expression, right to equal treatment, without discrimination, among others. That is, mere moral damage would suffice for the formatting of bullying.

In the sphere of law, attention must be paid to the damage to the protected legal right, which at present is identified as the moral integrity of the worker.

The level of severity of the damage when it affects the employee's health (psychic damage) is important when it comes to quantifying civil liability for bullying, but not as a key element in its constitution (Castro, 2014: p. 129). ${ }^{17}$

\subsection{Of the Willful Conduct}

It is essential for the configuration of moral harassment to establish the malicious conduct of the harassing agent, and it is not necessary to admit responsibility for culpable practice.

The malicious element is a mobbing, since there is a need for repeated practice that damages the dignity and personality of the worker whose ultimate aim ("special purpose of action") is the marginalization of the worker from the work environment, or the subjection to unfavorable conditions of work, among others (the role is not exhaustive).

In this context of moral harassment should be the question of malicious conduct in the same perspective of Criminal Law, being considered by Professor

16“'Dano psíquico não é, portanto, elemento para a caracterização do assédio moral”.

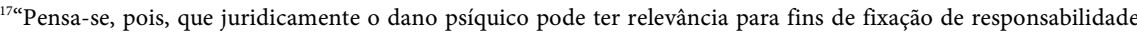
civil, mas não é imprescindível à configuração do mobbing". 
Zaffaroni \& Pierangeli (2005) in the following terms: “(...) it is convenient to conceptualize it as the objective will to achieve the objective type, guided by the knowledge of the elements of this in the specific case". ${ }^{18}$ (pp. 413-414)

Two elements are necessary to configure the intent: the intellectual (cognitive) and the volitional (emotional, intentional). That is, the harassing subject must be aware of the factual circumstances of the conduct he wishes to perpetrate (Greco, 2011: p. 183), ${ }^{19}$ as well as the will to want to accomplish it.

In the sphere of Criminal Law, fraud encompasses the following dimensions:

$O$ conhecimento do dolo compreende a realização dos elementos descritivos e normativos, do nexo causal e do evento (delitos de lesão), da lesão ao bem jurídico dos elementos da autoria e da participação dos elementos objetivos das circunstâncias agravantes e atenuantes que supõem uma maior ou menor gravidade do injusto (tipo qualificado ou privilegiado) e dos elementos acidentais do tipo objetivo. ${ }^{20}$ (Prado, 2010: p. 320)

Filtration for the labor field is a matter for the harasser to have effective knowledge that his conduct causes damage to the personality dimension of the worker, in addition to wanting the said harmful result.

It is not ruled out that guilty conduct (carried out in the face of negligence, recklessness and malpractice) may cause harm to the personality of the worker, however, would denature the figure of moral harassment.

The indispensability of malicious conduct is so obvious that when criminalizing the crime of sexual harassment (below), which constitutes a form of moral harassment of the worker, it only predicted the type in its malicious form, not predicting how much to the guilty. ${ }^{21}$

It is also pointed out that in guilty conduct there is a purpose (usually lawful) (Zaffaroni \& Pierangeli, 2005: p. 435), ${ }^{22}$ however, what matters in this conduct is whether or not the choice of the means by the agent to achieve the end violates the duty of care, where the right demanded the forecast of the result (Brandão, 2010: p. 182). ${ }^{23}$

In such a way, realize that the dogmatic structure of the guilty conduct is exactly the violation of the duty of care, where the choice of the means to reach the

${ }^{19}$ “A consciência, ou seja, o momento intelectual do dolo, basicamente, diz respeito à situação fática em que se encontra o agente. O agente deve ter consciência, isto é, deve saber exatamente aquilo que faz, para que se lhe possa atribuir o resultado lesivo a título de dolo. (...)".

${ }^{20}$ Free translation: "The knowledge of deceit comprises the realization of descriptive and normative elements, causal nexus and event (offenses of injury), injury to the legal good of the elements of authorship and participation of objective elements of aggravating and attenuating circumstances that suppose a greater or less seriousness of the unjust (qualified or privileged type) and of the accidental elements of the objective type".

${ }^{21}$ Código Penal. Art. 216-A. Constranger alguém com o intuito de obter vantagem ou favorecimento sexual, prevalecendo-se o agente da sua condição de superior hierárquico ou ascendência inerentes ao exercício de emprego, cargo ou função. Pena-detenção, de 1 (um) a 2 (dois) anos. Parágrafo único. (VETADO). $\$ 2^{\circ}$ A pena é aumentada em até um terço se a vítima é menor de 18 (dezoito) anos.

22“"O tipo culposo não individualiza a conduta pela finalidade e sim porque, na forma em que se obtém essa finalidade, viola-se um dever de cuidado, ou seja, como diz a própria lei penal, a pessoa, por sua conduta, dá causa ao resultado por imprudência, negligência ou imperícia. A circunstância de que o tipo não individualize a conduta culposa pela finalidade em si mesma não significa que a conduta não tenha finalidade, como parece terem entendido muito autores".

23“(...). O crime culposo é aquele onde há a falta de previsão do resultado, quando o Direito exigia do agente essa previsão, ou é aquele onde, havendo a efetiva previsão do resultado, o agente confia que ele não se configurara. (...)".
} 
end of the conduct is fundamental to attest to the duty of care.

From this explanation of the subjective element guilt that integrates the conduct to envisage that it could compose the systematic practice of violation of the dignity of the worker with corresponding moral damage.

\subsection{The Intensity of Violence}

A consensus on the need for a certain degree of intensity in violence perpetrated in a way that does not constitute an insignificant damage, easily absorbed by the worker, due to the normal conflicts in the labor negotiations.

In sum it is pointed out as the central gravity in the violence to the point of causing damage valued as not insignificant.

To attest that this level and intensity is not analyzed in regard to each conduct alone, but rather the set of actions (in its entirety) perpetrated by the stalker.

\section{The Legal Consequences of the Moral Harassment in the Context of the Labor Agreement}

As a result of moral harassment, whether vertical or horizontal, can terminate the employment contract.

In the case of vertical harassment this would entail the indirect termination of the employment contract, protecting all the labor rights of the harassed employee, according to a hypothesis of dismissal without just cause.

The normative basis for this is found in art. 483 from CLT:

Art. 483-The employee may consider rescinded the contract and claim the due indemnity when:

a) services superior to their forces are required, prohibited by law, contrary to good customs, or unrelated to the contract;

b) is treated by the employer or his superiors with excessive rigor;

c) to run a manifest danger of considerable harm;

d) failure to comply with the employer's obligations;

e) to practice the employer or his agents, against him or his family, an act detrimental to honor and good reputation;

f) the employer or his or her representatives physically offend him, except in the case of self-defense, his own or another's;

g) the employer reduces his or her work, this being by piece or task, in order to significantly affect the importance of wages. ${ }^{24}$ (Our Griffins)

It points out that bullying, by itself, in a general way, is already subsumed under the hypothesis of "not complying with the employer the obligations of the contract". However, in the present case, there will be situations in which more than one item of art. 483 of CLT as "practicing the employer or his agents, against him or persons of his family, act injurious to honor and good fame"; or to depend on the case "to run a manifest danger of considerable harm".

The pattern of indirect termination arising from harassment is quietly recog-

${ }^{24}$ Free translation. 
nized within the jurisprudence:

RESCISÃO INDIRETA E ASSÉDIO MORAL: A rescisão indireta do contrato laboral constitui falta máxima cometida pelo patrão, de modo a tornar insustentável a manutenção do contrato de trabalho. No caso em apreço, o assédio moral evidenciado constitui motivo para a configuração da rescisão indireta do contrato de trabalho na forma tipificada no septuagenário artigo 483 consolidado de 1943. Recurso ordinário não provido. ${ }^{25}$

Otherwise, in the case of horizontal harassment, it may lead to dismissal for just cause of the harassing employee, since bullying could be framed as conduct incontinence or malpractice; act of indiscipline; act injurious to the honor or good reputation practiced in the service against any person, or physical offenses, under the same conditions.

Art. 482-The employer is entitled to terminate the employment contract as a just cause:

a) act of improbity;

b) conduct incontinence or poor procedure;

c) habitual negotiation on his own account or on his own behalf without permission of the employer, and when it constitutes an act of competition to the company to which the employee works, or is harmful to the service;

d) criminal conviction of the employee, which is final and unappealable, if there has been no suspension of execution of the sentence;

e) depreciation in the performance of their functions;

f) habitual drunkenness or in service;

g) breach of company secrecy;

h) act of indiscipline or insubordination;

i) abandonment of employment;

j) act prejudicial to the honor or good reputation practiced in the service against any person, or physical offenses, under the same conditions, except in case of self-defense, own or others;

k) act prejudicial to the honor or good reputation or physical offenses committed against the employer and hierarchical superiors, except in case of self-defense, own or others;

1) constant practice of gambling. ${ }^{26}$ (Our Griffins)

\section{The Distinction between Moral Harassment and Sexual Harassment}

Apart from what happens with the figure of bullying, sexual harassment is cri-

${ }^{25}$ TRT da $2^{\circ}$ região, $11^{\circ}$ turma, RO 1001734-51.2014.5.02.0501, relator Desembargador Ricardo Verta Luduvice, DEJT de 15/03/2016. Free translation: "Indirect termination and moral harassment: The indirect termination of the labor contract constitutes a maximum fault committed by the employer in order to render the maintenance of the employment contract untenable. In the present case, the moral harassment evidenced constitutes a reason for the configuration of the indirect termination of the employment contract in the form typified in the septuagenarian Article 483 consolidated of 1943 . Ordinary remedy not provided".

${ }^{26}$ Free translation. 
minalized and has been inserted into the Penal Code by Law 10.244/01.

The criminal type of sexual harassment is thus prescribed in art. 216-A of the Penal Code:

Art. 216-A. To embarrass someone with the purpose of gaining advantage or sexual favor, prevailing the agent of his status as superior or inherent in the pursuit of employment, position or function.

Penalty-detention, from 1 (one) to 2 (two) years. ${ }^{27}$

Note that the core of the type is the conduct of embarrassment, being this without violence or serious threat, which would denature the crime of sexual harassment to the sphere of another criminal type.

Sexual harassment is, in fact, a form of moral harassment at work, with the sexual element being the aggressor's special purpose (the active subject of the offense), resulting in repercussions not only on the labor and civil sphere but also on in the criminal.

By the prescription of elements of the criminal type, in its final part "(...) prevailing the agent of his status as superior or inherent inherent in the exercise of employment, position or function," it is noted that the only way to sexual harassment that would constitute a crime would be that perpetrated in a descending (vertical descending moral harassment).

That is, horizontal sexual harassment, practiced by coworkers, or in the ascending modality, of the subordinate in relation to the hierarchical superior, constitute, as previously seen, in forms of moral harassment, but not in a criminal type.

Sexual harassment can occur both in the public sphere of work and in the private sector. The existing controversy, although not much more practical, refers to the fact that jurists interpret that the normative element of the type "hierarchical superior... inherent in the exercise of employment, position or function" was to be governed by the principle of hierarchy, while the "(...) inherent in the exercise of employment, position or function" would relate to the private sphere of employment (Greco, 2011: p. 518) (Nucci, 2015: p. 1219) (Cf. Masson, 2013: pp. 47-48). ${ }^{28}$

In a brief survey on the subject, in the context of the jurisprudence, ${ }^{29}$ it argues

\footnotetext{
${ }^{27}$ Free translation.

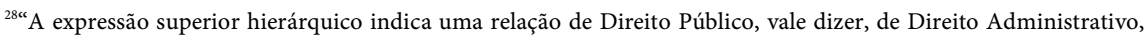
não se incluindo, as relações de Direito Privado. Para que a máquina administrativa possa funcionar com eficiência preciso que exista uma escala hierárquica entre aqueles que detêm o poder de mando e seus subordinados. (...). Isso significa que não há relação hierárquica entre particulares, como no caso do gerente de uma agência bancária e seus subordinados, bem como inexiste tal relação nas hipóteses de temor reverencial entre pais e filhos ou mesmo entre líderes religiosos e os fiéis. No entanto, poderia haver a prática do delito de assédio sexual, por exemplo, entre um coronel e alguém de uma patente menor, (...). Enfim, visualizando-se a relação de Direito Público, seria possível o reconhecimento do assédio sexual". "Superior hierárquico: trata-se de expressão utilizada para designar o funcionário possuidor de maior autoridade na mesma estrutura administrativa pública, civil ou militar, que possui poder de mando sobre os outros. Não se admite, nesse contexto, a relação de subordinação existente na esfera civil. (...). Ascendência: significa superioridade ou preponderância. No caso presente, refere-se ao maior poder de mando, que possui um indivíduo, na relação de emprego, com relação a outro. Liga-se ao setor privado, (...). Não há qualquer possibilidade de haver assédio sexual quando envolver empregados de igual escalão, nem tampouco quando o de menor autoridade assediar o de maior poder de mando".

${ }^{29} \mathrm{~A}$ questão não fora ventilada no seio do STJ.
} 
that the hierarchical superiority element would also cover the labor field and not only of the Public Administration (Bitencourt, 2010: p. 81), (Franco \& Stoco, 2007: pp. 1061-1062). ${ }^{30}$ as in the judgment of the Court of Justice of Rio Grande do Sul that recognized sexual harassment in the case of domestic servant:

APELAÇÃO CRIMINAL. CRIMES SEXUAIS. ASSEDDIO SEXUAL MAJORADO. MATERIALIDADE E AUTORIA.

Não prevalece a alegação de insuficiência de provas relativamente à materialidade e autoria do crime de assédio sexual imputado ao réu, tendo em vista o robusto e concludente conjunto probatório coligido aos autos, de onde se destaca o relato da vítima, que demonstrou que o réu, aproveitando-se da sua superioridade hierárquica, pois que à época do fato era o empregador da ofendida, agarrou-a contra a sua vontade tentando lhe dar um beijo. DOSIMETRIA DA PENA. Mantido o apenamento aplicado na sentença, porquanto evidenciado que está em sintonia com os critérios de necessidade e suficiência para a reprovação e prevenção do crime. APELAÇÃO A QUE SE NEGA PROVIMENTO. ${ }^{31}$

In view of this we can make some assumptions: 1) every sexual harassment necessarily characterizes a moral harassment; 2) not all sexual harassment would be a crime, but only that practiced in a vertical descending relation.

We agree that the doctrine that questions the need to create the criminal type of sexual harassment, since the matter is better dealt with by other branches of law (labor law, civil law, administrative law), and Criminal Law should be the last ratio, in the dictates of the principle of minimum intervention, (Masson,

\footnotetext{
30“A relação superior-subalterno pode existir na seara pública e na seara privada. Na relação hierárquica há uma escala demarcando posições, graus ou postos ordenados configuradores de uma carreira funcional. $\mathrm{Na}$ ascendência, contrariamente, não existe essa organização funcional, mas tão somente uma situação de influência ou respeitoso domínio, podendo atingir, inclusive, o nível de temor reverencial. Nesse sentido, discordamos do entendimento esposado por Guilherme Nucci, segundo o qual, a superioridade hierárquica retrata uma relação laboral no âmbito público, enquanto a ascendência reflete a mesma relação, porém, no âmbito privado, ambas inerentes ao exercício de emprego, cargo ou função. Na verdade, a ascendência não se vincula a qualquer relação laboral, funcional ou trabalhista, no âmbito público ou privado, como destacamos. Cargo e função referem-se ao setor público, disciplinado pelo Direito Administrativo; emprego expressa a relação empregatícia no setor privado. O Código Penal brasileiro disciplina a obediência hierárquica (art. 22, segunda parte), "que requer uma relação de direito público, e somente de direito público. A hierarquia privada, própria das relações da iniciativa privada, não é abrangida por esse dispositivo". O subordinado não tem o direito de discutir a oportunidade ou conveniência de uma ordem. Considerando que o subordinado deve cumprir ordem do superior, desde que essa ordem não seja manifestamente ilegal, pode-se concluir os abusos que um superior mal-intencionado pode praticar quando, por exemplo, for movido por desvio de conduta, especialmente se alimentada por interesses libidinosos. Embora a "hierarquia privada" não receba a mesma disciplina no $\mathrm{CP}$, com as devidas cautelas, mutatis mutandis, os abusos também podem ser gravemente praticados contra quem se encontre em condição de inferioridade, na relação de trabalho ou emprego". "Na situação de superioridade hierárquica, se detecta um relacionamento que diz respeito à hierarquia decorrente de uma organização funcional, que pode dar-se tanto nas relações laborais de direito público quanto nas de direito privado: as elementares cargo e função são conceitos que dizem respeito ao serviço público, enquanto que emprego faz referência às relações trabalhistas inerentes ao setor privado, onde uma pessoa presta serviços ao empregador mediante salário no regime regido pela C.LT. A ascendência apresenta um outro aspecto, não se vinculando a qualquer hierarquia, mas sim a uma relação de domínio, de influência ou mesmo o temor reverencial, porém referentes também às relações laborais, em seu sentido amplo".

${ }^{31}$ Tribunal de Justiça do RS, Apelação Crime n 70065105108, Sétima Câmara Criminal, Relator: José Conrado Kurtz de Souza, Julgado em 05/11/2015. "CRIMINAL APPEAL. SEXUAL CRIMES. MAJORADO SEXUAL HARM. MATERIALITY AND AUTHORITY. The allegation of insufficient evidence regarding the materiality and authorship of the crime of sexual harassment imputed to the defendant does not prevail, in view of the robust and conclusive set of evidence collected from the case file, which highlights the victim's report, which showed that the defendant, taking advantage of his hierarchical superiority, since at the time of the fact he was the employer of the offended, he caught her against his will trying to give him a kiss. DOSIMETRIA OF THE PENALTY. Maintained the apprehension applied in the sentence, as evidenced that it is in line with the criteria of necessity and sufficiency for the reprobation and prevention of crime. TO WHICH Dismissal".
} 
2013: pp. 45-46) $)^{32}$ thus forming another example of symbolic criminal law, whose criminal infraction, pragmatically, will end within the special criminal courts, or with a conditional suspension of the process (minimum sentence of up to one year), ${ }^{33}$ or with a criminal transaction (maximum penalty of up to 2 years), ${ }^{34}$ since they face a crime of less offensive potential.

It is in this same sense the harsh criticism of (NUCCI, 2015) regarding the criminal type of sexual harassment:

(...) cremos ser totalmente inadequada e inoportuna a criação do delito de assédio sexual no Brasil. Primeiramente, deve-se ressaltar que são poucos os casos noticiados de importunações graves, no cenário das relações de trabalho, que não forma devidamente solucionados, com justiça, nas esferas cível e trabalhista-ou mesmo administrativa, quando se cuidar de funcionário público. Em segundo lugar, é preciso considerar que, para o nascimento de uma nova figura típica incriminadora, seria indispensável levar em conta o conceito material de crime, insto é, o fiel sentimento popular de que uma conduta merecesse ser sancionada com uma pena, o que não ocorre. Trata-se de um delito natimorto, sem qualquer utilidade pública, o que p tempo irá demonstrar. Não se desconhece que o assédio sexual é uma realidade em todo o mundo, merecendo punição, além de ser nitidamente ilícito, antiético e imoral, mas não se trata de assunto para o direito penal. Podemos insistir que, em vez de descriminalização, observamos o fenômeno inverso, consistente no surgimento de maus uma figura incriminadora, desconsiderando-se o ser o direito penal a ultima ratio, ou seja, a última cartada do legislador para a punição de condutas verdadeiramente 'serias e comprometedoras da tranquilidade social. Não é o caso do assédio sexual, fruto da importação de normas de outros sistemas legislativo, inadequados à realidade brasileira. Enfim, melhor teria sido a previsão, se fosse o caso, de maior rigidez na punição de empregadores e funcionários, nos campos civil, trabalhista e administrativo, do que ter criado um outro tipo penal, cuja margem de aplicação será diminuta, quando não for geradora de erros judiciários consideráveis, até mesmo porque a prova de uma existência será extremamente complexa. (...). Em suma, a solução legislativa para os casos de assédio sexual, tipificando-a, não foi acertada, em nosso entender. ${ }^{35}$ (pp. 1217-1218)

\footnotetext{
32“As condutas dessa estirpe, covardes e repugnantes, indiscutivelmente merecem rígida punição, mas fora da órbita penal. Se o legislador esqueceu-se do caráter fragmentário do Direito Penal, criando um crime quando a ilicitude era resolvida por outros ramos do ordenamento jurídico, na prática o tipo penal quase não é usado, em obediência ao princípio da subsidiariedade (ultima ratio)".

${ }^{33}$ Lei $n^{\circ} 9.099 / 95$. Art. 89. Nos crimes em que a pena mínima cominada for igual ou inferior a um ano, abrangidas ou não por esta Lei, o Ministério Público, ao oferecer a denúncia, poderá propor a suspensão do processo, por dois a quatro anos, desde que o acusado não esteja sendo processado ou não tenha sido condenado por outro crime, presentes os demais requisitos que autorizariam a suspensão condicional da pena (art. 77 do Código Penal).

${ }^{34}$ Lei $n^{\circ} 9.099 / 95$. Art. 76. Havendo representação ou tratando-se de crime de ação penal pública incondicionada, não sendo caso de arquivamento, o Ministério Público poderá propor a aplicação imediata de pena restritiva de direitos ou multas, a ser especificada na proposta.

${ }^{35}$ Free translation: “(...) we believe that the creation of the crime of sexual harassment in Brazil is totally inadequate and inopportune. First of all, it should be noted that there are few reports of serious harassment in the labor relations scenario, which are not properly resolved in the civil and labor spheres-or even administrative, when
} 


\title{
From Proposed Law No. 5.971/01
}

Of particular note is Bill No. 5,971/01 of the former federal deputy Inácio Arru$\mathrm{da}$ and others with the purpose of characterizing the conduct of bullying, adding art. 203-A in the Criminal Code with the name iures of "moral coercion in the workplace":

Art. 203-A. To coerce morally employed in the work environment, through acts or expressions that aim to achieve dignity or create humiliating or degrading working conditions, abusing the authority conferred by the hierarchical position.

Penalty-detention, from 1 (one) to 2 (two) years and fine. ${ }^{36}$

The same considerations presented regarding the criminalization of sexual harassment and the normative vector of the minimum intervention of Criminal Law applies the proposal of criminalization of moral harassment. (Carvalho \& Carvalho, 2006: pp. 2018-2019) $)^{37}$

Finally, it is important to emphasize that although we do not agree with the creation of a specific criminal type in relation to bullying, the various harassing behaviors end up slipping into several existing criminal types such as libel, defamation, threat, illegal embarrassment, violation of freedom of work, etc.

\section{Conclusion}

Labor harassment, although not a new phenomenon, has been highlighted by its

\begin{abstract}
caring for a civil servant. Secondly, it is necessary to consider that, for the birth of a new incriminating typical figure, it would be indispensable to take into account the material concept of crime, I urge, the faithful popular feeling that a conduct deserves to be sanctioned with a sentence. does not occur. It is a crime stillborn, without any public utility, which time will demonstrate. It is not unknown that sexual harassment is a reality around the world, deserving punishment, besides being clearly illicit, unethical and immoral, but it is not a matter for criminal law. We can insist that, instead of decriminalization, we observe the inverse phenomenon, consisting in the appearance of bad an incriminating figure, disregarding the criminal law being the ultima ratio, that is, the last lawmaker's suit for the punishment of truly 'serious and compromising of social tranquility. It is not the case of sexual harassment, the result of the importation of norms from other legislative systems, inadequate to the Brazilian reality. Finally, it would have been better, if it were the case, to have been more rigid in the punishment of employers and civil servants in the civil, labor and administrative fields than to have created another type of criminal offense. causing considerable miscarriages of justice, even because the proof of existence will be extremely complex. (...). In short, the legislative solution to cases of sexual harassment, typifying it, was not correct, in my view".

${ }^{36}$ Free translation.

${ }^{37} \mathrm{~A}$ favor pela tese da criminalização do assédio moral laboral é a corrente defendida por CARVALHO \& CARVALHO. "Tudo quanto foi dito anteriormente põe em evidência a necessidade de criação de um tipo penal específico e novo no âmbito dos "Crimes contra a Organização do Trabalho" (Título IV do Código Penal), através do qual fosse criminalizada uma conduta com as características do assédio moral nas relações de trabalho. Já vimos como os atuais tipos penais resultam insuficientes para a repressão do assédio psicológico no ambiente laboral. Só através da criação dessa nova figura delitiva, será possível fazer com que os assediadores conheçam a conduta proibida pela norma e sua punição, e os assediados saibam a partir de que momento o assédio ultrapassa os limites do permitido e é possível contar com a proteção da legislação penal. Também seria conveniente que essa proposta de criminalização viesse acompanhada pela devida reforma da legislação trabalhista (Consolidação das Leis do Trabalho), da qual deveria constar expressamente a proibição do assédio moral e o direito dos trabalhadores a não sofrê-lo, além da específica sanção para o empregado ou empregador que desrespeitasse tal normativa". (...) "Conforme destacado anteriormente, o tratamento atual do assédio moral nas relações de trabalho no ordenamento brasileiro resulta extremamente insatisfatório, já que o máximo de proteção que pode obter o trabalhador assediado, no âmbito do Direito Laboral, é a rescisão unilateral do contrato de trabalho, o que acarreta a necessidade de que seja ele quem abandone o seu posto de trabalho e, o que é pior, muitas vezes permite que o assediador ou assediadores fiquem completamente impunes. Por outro lado, não parece ser que os tipos penais dos delitos já existentes na legislação brasileira (lesões corporais, injúria, difamação, assédio sexual, constrangimento ilegal, ameaça, etc.) possam encerrar com precisão todo o conteúdo do injusto específico do assédio moral no ambiente de trabalho".
\end{abstract}


increasingly consistent recognition in the field of labor claims, following Constitutional Amendment 45/04.

The definition of labor mobbing does not find support in any heteronomous source within the Brazilian legal system, at least in the sphere of private relations, which has led to several divergences as to the elements and limits of the characterization of occupational moral harassment which puts the mentioned phenomenon in a pattern of certain legal insecurity.

We understand that the figure of moral harassment in the workplace is set when necessarily present the malicious conduct that results in harmful to the dignity of the worker, being related to the labor context, in a repeated and systemic way, being perpetrated with a certain intensity of violence.

In the face of a vertical harassment, this would entail the indirect termination of the employment contract. Already when horizontal harassment can lead to dismissal for just cause of the harassing employee seen as being framed as conduct incontinence or bad procedure; act of indiscipline; act injurious to the honor or good reputation practiced in the service against any person, or physical offenses, under the same conditions.

Regarding the distinction between bullying and sexual harassment, the following premises are taken: 1) every sexual harassment necessarily characterizes a moral harassment; 2) not all sexual harassment would be a crime, but only that practiced in a vertical descending relation.

At first, we do not agree with the bill that criminalizes the conduct of bullying as a crime, since Criminal Law is the last ratio, in the dictates of the principle of minimum intervention, thus configuring another example of symbolic criminal law, punishable by the criminal courts, either with a conditional suspension of the process (minimum sentence of up to one year), or with a criminal transaction (maximum penalty of up to 2 years), as he faces a criminal offense, less offensive potential.

The updating of the CLT is pressing in order to create a proper chapter on the figure of bullying so that the legal uncertainty surrounding this matter is remedied, which would allow a better normative basis with the object to combat this odious practice, inconceivable in a so-called global law that has the primacy of the dignity of the human person as the maximum vector.

\section{References}

Bitencourt, C. R. (2010). Tratado de Direito Penal-Parte especial (4º ed., Vol. IV). São Paulo: Saraiva.

Brandão, C. (2010). Curso de Direito Penal-Parte geral (2ºd.). Rio de Janeiro: Forense.

Carvalho, G. M., \& Carvalho, É. M. (2006). O Assédio moral nas relações de trabalho: Uma proposta de criminalização. In Anais do XV Congresso Nacional organizado pelo Conpedi (pp. 2910-2925). Manaus.

http://www.publicadireito.com.br/conpedi/manaus/arquivos/anais/brasilia/05_841.pdf

Castro, C. R. (2014). O que você precisa saber sobre o assédio moral nas relações de emprego ( $2^{\circ}$ ed.). São Paulo: LTr. 
Franco, A. S., \& Stoco, R. (2007). Código penal e sua interpretação ( $8^{\circ}$ ed). São Paulo: RT.

Greco, R. (2011). Curso de Direito Penal-Parte geral (13º ed., Vol. III). Rio de Janeiro: Impetus.

Hirigoyen, M.-F. (2002). Assédio moral: A violência perversa no cotidiano (5º ed., Trad. by Kühner, M.H.). Rio de Janeiro: Bertrand Brasil.

Leymann, H. (1990). Mobbing and Psychological Terror at Workplaces. Violence and Victims, 5, 119-126. http://www.mobbingportal.com/LeymannV\&V1990(3).pdf https://doi.org/10.1891/0886-6708.5.2.119

Martins, S. P. (2015). Assédio moral no emprego (4º ed.). São Paulo: Atlas.

Masson, C. (2013). Direito Penal esquematizado-parte especial (3ºd., Vol. 3). São Paulo: Método.

Nucci, G. S. (2015). Código Penal comentado ( $15^{\circ}$ ed). São Paulo: Forense.

Prado, L. R. (2010). Curso de Direito Penal brasileiro (8º ed., Vol. I). São Paulo: Revista dos Tribunais.

Soares, F. D., \& Duarte, B. H. (2014). O assédio moral no ordenamento jurídico brasileiro (pp. 21-47). Fórum Trabalhista-RFT(11).

Zaffaroni, E. R., \& Pierangeli, J. H. (2005). Manual de direito penal brasileiro (6º ed., Vol. I). São Paulo: RT. 